\title{
肺癌胃転移と考えられる 1 例
}

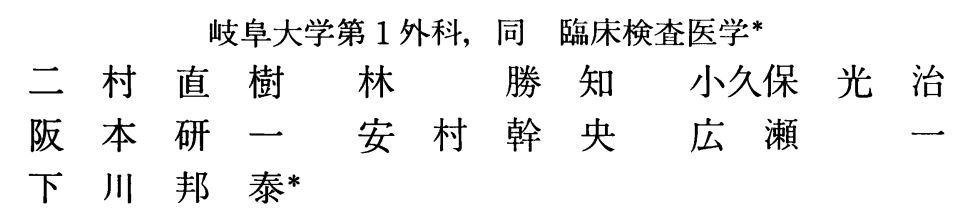

\section{A Case of Gastric Metastasis from Polmonary Carcinoma}

\author{
Naoki FUTAMURA, Masatomo HAYASHI, Mitsuharu KOKUBO, \\ Ken-ichi SAKAMOTO, Mikio YASUMURA, Hajime HIROSE \\ and Kuniyasu SHIMOKAWA*
}

First Department of Surgery and Department of Laboratory Medicine*, Gifu University School of Medicine

肺と胃に腺癌を認め, 胃病変の粘膜下腫瘍様の形態から肺癌胃転移と考えられる 1 例を経験した。症例は50歳 の女性。主訴は左大腿部痛。1998年 1 月, 左大腿部に小児頭大の腫瘤を認め, 整形外科に入院した。左大腿部腫 瘤の生検が行われ，低分化腺癌と診断された。転移性腫瘍と診断され，原発巣の検索が行われた。精査の結果， 肺，胃および副腎に病変を指摘された。胃の病変は中心に潰瘍をともなうなだらかな隆起でbull's eye signであ った。2 期的に胃と右副腎，右肺と左大腿の病変をそれぞれ切除した。病理組織検査では 4 病変はいずれも低分 化腺癌で同様の組織像であった。胃の病変は粘膜下腫瘍様の形態であった。肺癌の胃，右副腎，左大腿軟部組織 転移と診断した。術後に化学療法としてシスプラチン $60 \mathrm{mg} / \mathrm{m}^{2}$, ビンデシン $2 \mathrm{mg} / \mathrm{m}^{2}$ を 1 クール投与した。 2 回 目の手術から約11カ月後に再発で死亡した。

索引用語：転移性胃癌（gastric metastasis）, 肺癌（pulmonary carcinoma）, bull's eye sign

\section{はじめに}

転移性胃癌, 粘膜下腫瘍梯の原発性胃癌はとも にまれな疾患である。今回われわれは，胃に粘膜 下腫瘍様の病変を認め, 肺癌の転移性胃腫瘍と考 えられる 1 例を経験したので報告する。

\section{症例}

患 者：50歳，女性。

主 訴: 左大腿部痛。

家族歴：特記すべきことなし。

既往歴：9 歳, 両側鼠径へルニア根治術。

現病歴：1997年 9 月頃から左大腿から下腿の痛
みを自覚していた。痛みが増強し，大腿に腫瘤を 触知するようになったため，12月に近医を受診し た。左大腿軟部組織腫瘍の診断で当院整形外科に 紹介され，1998年 1 月に入院した。

入院時現症: 左大腿に弾性硬, 境界明暸な小児 頭大の腫瘤を触知した。

入院後経過：左大腿部腫瘤の生検が御われ, 腺 癌と診断された。転移性と診断し, 原発巣の検索 を行った。精査の結果, 肺, 胃および副腎に病変 を指摘された。

入院時血液検查 : 血液一般および生化学検查で 異常を認めなかった。腫瘍マーカーはCA19-9が $127.1 \mathrm{U} / \mathrm{ml}$ と上昇していた。CEAは正常であった。 

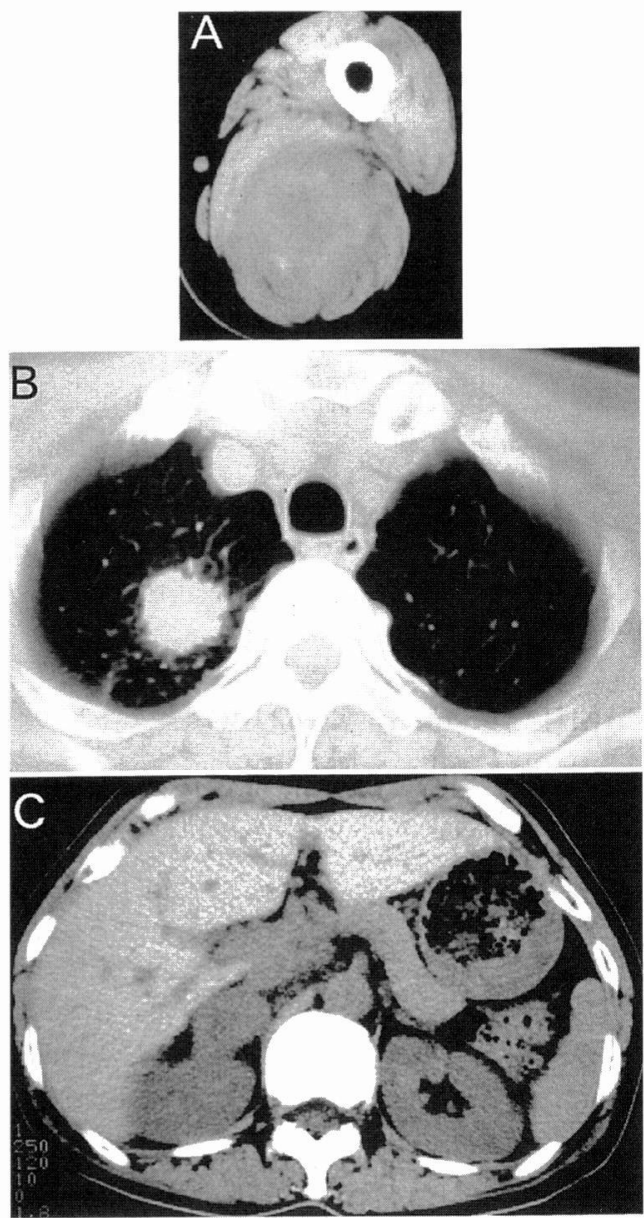

Fig. 1 Computed tomography demonstrated a tumor in the size of $8 \times 8 \mathrm{~cm}$ in the left thigh (A), a tumor with the irregular border in the size of $3 \times 2.8 \mathrm{~cm}$ in $\mathrm{S} 1$ of the right lung $(B)$ and a tumor in the size of $5.5 \times 3 \mathrm{~cm}$ in the right adrenal gland (C).

胸部X線検査：右上肺野に辺縁不整で内部ほぼ 均一な約 $3 \mathrm{~cm}$ 大の陰影を認めた。

CT検査：左大腿に $8 \times 8 \mathrm{~cm}$ 大の腫瘤を認女， 骨格筋転移と考之られた (Fig. 1A)。右肺S1に辺 縁不整な $3 \times 2.8 \mathrm{~cm}$ 大の腫瘤を認女た $($ Fig. 1B)。 右副腎に $5.5 \times 3 \mathrm{~cm}$ 大の腫瘤を認めた $($ Fig. 1C)。

上部消化管造影検査：胃体中部後壁に中心に潰 瘍をともなう隆起を認めた（Fig. 2)。

上部消化管内視鏡検査：胃体中部後壁に中心潰 瘍をともなうなだらかに隆起を認め, 粘膜下腫痬 様であった (Fig. 3)。

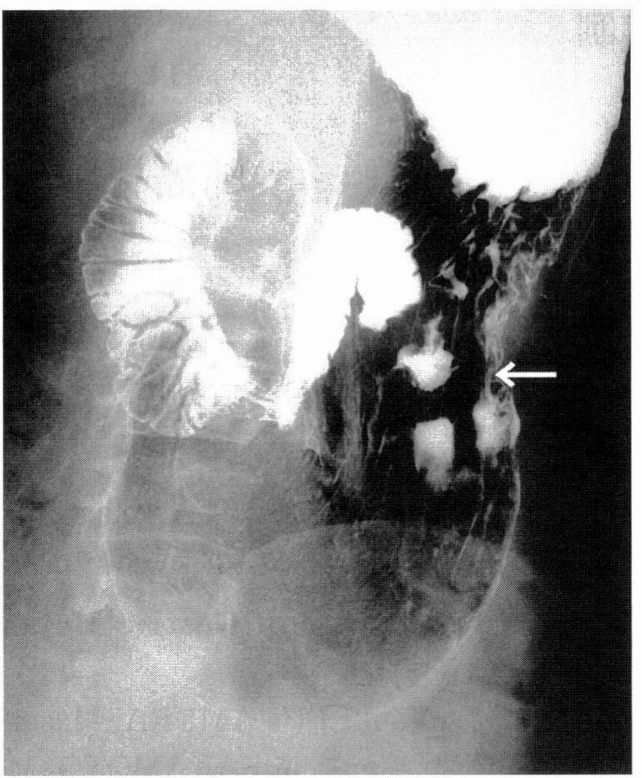

Fig. 2 Upper gastrointestinal radiography showed a protruding lesion with central ulceration (arrow) on the posterior wall of the middle body of the stomach.

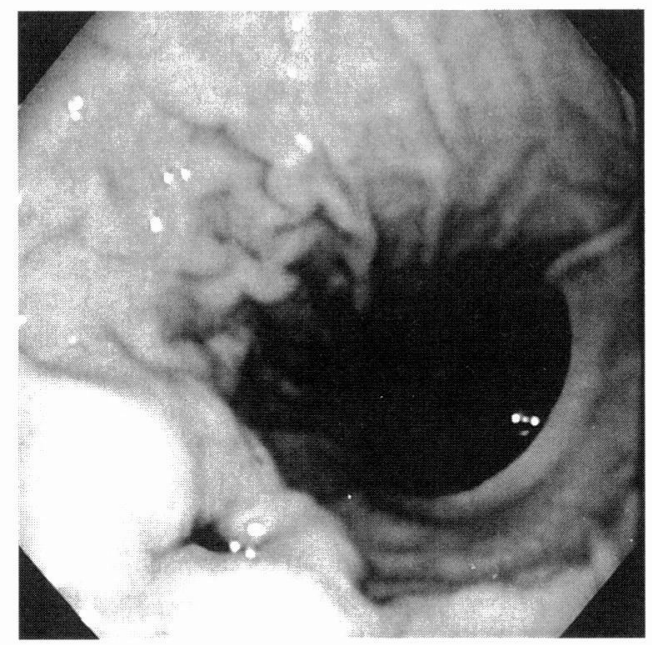

Fig. 3 Endoscopic examination demonstrated a smoothly protruding lesion with central ulceration on the posterior wall of the middle body of the stomach.

肺と胃は生検にてともに低分化腺癌で同様の組 織像であり，これらと左大腿の生検も同様であっ た。

以上より，肺あるいは胃が原発で 3 力所に転移 


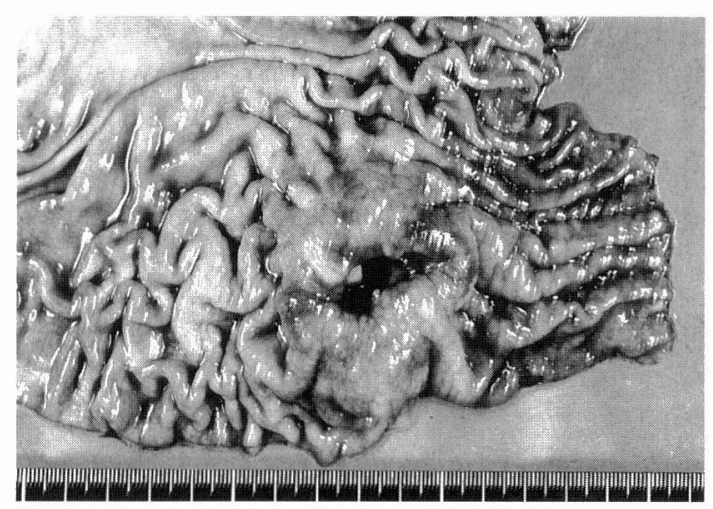

Fig. 4 Resected specimen of the stomach showed a smoothly protruding lesion with central ulceration on the posterior wall of the middle body.

性病変を認めると診断した。画像診断では各病巣 は切除可能と考えられた。患者と家族に病状を説 明し，各病巣で切除してその後に化学療法を行う ことで同意が得られた。2 期的に胃と右副腎, 右 肺と左大腿の病変をそれぞれ切除することとし た。1998年 4 月に手術を行った。

手術所見：腹腔内は胃と副䝳以外に明らかな病 変を認めなかった。D2郭清をともなう幽門側胃切 除術，右副腎摘出術を行った。

標本所見：体中部後壁に $6.0 \times 4.8 \mathrm{~cm}$ 大の中心 潰瘍をともなう隆起性病変を認めた。潰晹の周囲 はなだらかに隆起して平滑な粘膜に被われ, 粘膜 下腫瘍様であった (Fig. 4)。右副腎腫瘍は, $8.0 \times$ $4.5 \mathrm{~cm}$ 大で灰白色，充実性であった。

病理組織学的所見：胃では腫瘍細胞が小胞巣を 形成し, 粘膜下組織から筋層を中心に粘膜から漿 膜下組織まで浸潤増生していた。低分化腺癌（胃 癌取扱い規約に準ずると por2）と諩断した（Fig. $5,6)$ 。リンパ節転移はなかった。右副盘も胃と同 様に低分化腺癌であった。

術後経過は良好であった。術後に測定したCA19 -9は140.4U/mlと上昇していた。狊の粘膜下腫瘍 様の肉眼所見, 病変が粘膜下組織から筋層を中心 に存在する病理組織所見, 上部消化管造影の所見 がbull's eye sign ${ }^{12)}$ と考えられることから肺が原 発の可能性が高いと考えた。術後38日目に右肺癌 と左大腿腫瘍に対して手術を行った。

手術所見：腹臥位として左大腿の腫瘍を周囲の

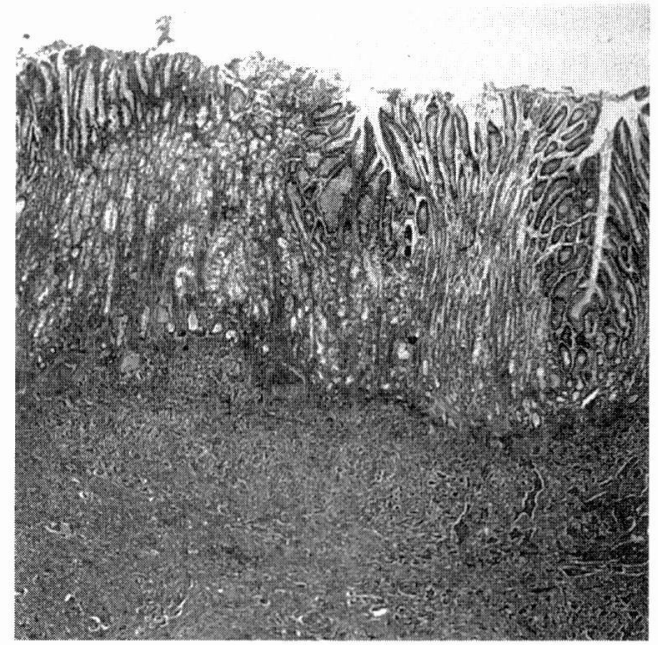

Fig. 5 Tumor cells were chiefly located in the submucosal and proper muscle layers, and thrusted up the normal mucosa from underneath (H. E., ×3.3).

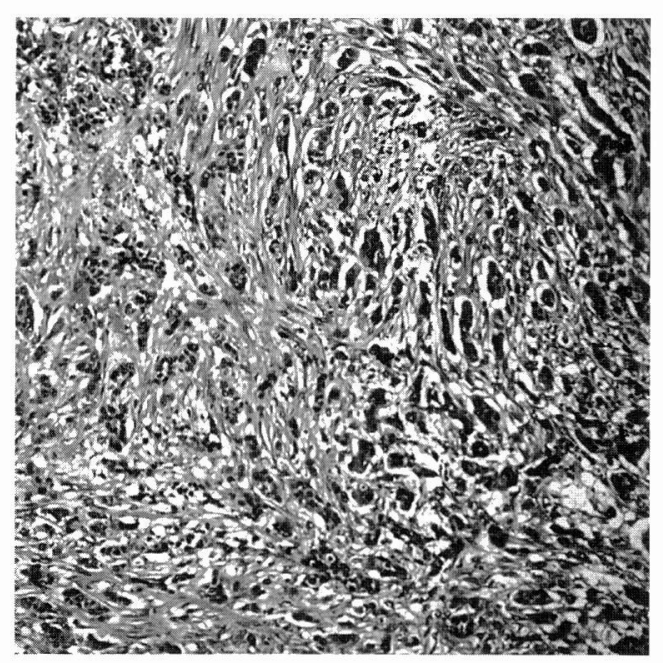

Fig. 6 Microscopic findings of the gastric tumor showed poorly differentiated adenocarcinoma $(H . E ., \times 100)$.

筋肉と一塊に切除した。その後, 左側卧位として 開胸し, R 2a郭清をともなう右上葉切除術を行っ た。胸膜播種を認めなかった。

標本所見：右肺 $\mathrm{S} 1+2$ に $4 \times 3.5 \times 3 \mathrm{~cm}$ 大, 弾 性硬, 割面にて灰白色の腫瘤を認めた。左大腿の 腫瘍は $27 \times 14 \times 10 \mathrm{~cm}$ 大で約 $2 \mathrm{~kg}$ であった。弾性 硬で割面は黄白色であった。 
病理組織学的所見 : 右肺, 左大腿ともに腫瘍細 胞が小胞巣を形成し，低分化腺癌と診断した。胃， 副腎の組織像と同様であった。肺癌の郭清リンパ 節に転移を認めなかった。

術後経過は良好であった。術後に測定したCA19 -9 は $13.9 \mathrm{U} / \mathrm{ml}$ と正常化していた。術後に化学療法 としてシスプラチン $60 \mathrm{mg} / \mathrm{m}^{2}$, ビンデシン $2 \mathrm{mg} /$ $\mathrm{m}^{2}$ を投与した。嘔気, 全身倦急感などの副作用が 強く, 本人が化学療法の継続を同意しなかったた め，1コースのみ投与して 8 月に退院した。1999 年 1 月, 後頝部に母指頭大の皮下腫瘤を触れ, 再 発と診断した。退院後は1999年 2 月までCEA, CA19-9は正常值であった。3 月に食欲不振を主訴 に入院し，4月に永眠となった。

剖検所見 : 右肺中葉 -下葉, 左肺上葉 -下葉, 左副腎, 腹部大動脈周囲リンパ節に転移を認めた。

\section{考察}

本症例は腺癌であったため, 原発臓器が肺であ るのか胃であるのかが問題であった。胃病変が肉 眼的, 病理組織学的に粘膜下腫瘳様であったため 肺癌胃転移と考えた。

転移性胃癌は稀な疾患であり, 悪性腫瘍剖検例 の0.3 2.3\%で, 原発巣は, 食道癌, 肺癌, 乳癌, 膵臓癌, 前立腺癌, 黒色腫などの頻度が高いこと が報告されている(3) 6)。転移性胃腫瘍の特徵的な 形態は，滑らかな辺縁をもつ隆起で中心に潰瘍を 伴い, X線学的にbull's eye sign, あるいはtarget sign と呼ばれている ${ }^{12) 5)}$ 。本症例も bull's eye sign を認めた。佐野 ${ }^{3)}$ は転移性胃腫瘍37例中29例 (78.3 \%)と高頻度にbull's eye signを認めたと報告して いる。生前に肺癌の転移性胃病変を指摘されるこ とは稀であり，そのような症例はわれわれが調べ えた範囲で，本邦で41例が報告されていた。これ らについて検討した。胃病変の個数は単発が 24 例 (59\%)，多発が17例 (41\%) であった。腫瘤の形 態は, bull's eye signと記載されたものが 9 例 (22 \%), 中心に潰瘍, 陥凹を伴う粘膜下腫瘍と記載さ れたものが 7 例 (17\%), 中心潰瘍を伴う隆起と記 載されたものが 6 例 (15\%), Borrmann 2型様と 記載されたものが 4 例（10\%）であり，中心に潰 瘍, 陉凹を有する隆起性病変の形態をしたものが
多かった。病変の部位を単発症例で検討すると, 弯蕯部 6 例, 胃体部13例, 胃角部 3 例, 前庭部 2 例であり，胃体部に多かった。組織型は小細胞癌 13 例, 扁平上皮癌12例, 大細胞癌 8 例, 腺癌 6 例, 未分化癌 2 例であった。胃転移発見時に他臟器に も転移を認めた症例が多く，記載のあった 33 例中 23例（70\%）であった。本症例は副腎に転移を認 めたが，副腎転移は剖検が行われた本邦報告例14 例中10例 (71\%) と高頻度であった。上原ら 検例の検討から肺癌胃転移例における副腎転移合 併が $65.3 \%$ と高頻度であることを報告している。 肺癌剖検例における副腎転移は $20.3 \sim 34.6 \% \%^{8) \sim 10)}$ と報告されており，これらと比較して肺癌胃転移 例の副腎転移は高頻度で特徵的と考えられた。本 症例は胃体部に存在すること, 副腎転移があるこ とがこれまでの報告例の特徴と一致していた。

一方, 粘膜下腫瘍の形態を示した原発性胃癌も まれな疾患であり，胃癌の $0.24 〜 0.62 \%$ と報告さ

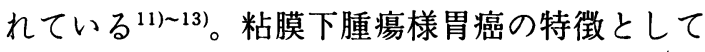
は，M領域やL領域に多い，頂部に潰瘍ないし陥凹 を認めることが多い, 組織型では por 1や粘液癌が 多い, 組織学的にリンパ球浸潤, あるいは線維化

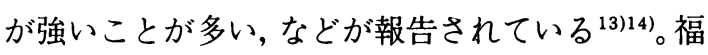
山ら ${ }^{11)}$ は粘膜下腫瘍様胃癌と転移性胃癌は鑑別性 に乏しく，胃以外の悪性病変の有無ないし既往を 知っておいて転移を疑うことが必要と報告してい る。本症例の原発部位が胃の場合は肺病変は単発 の肺転移となる。胃癌の肺転移はリンパ管症型が

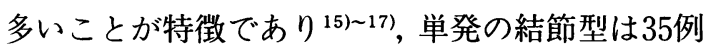
中 2 例 $(5.7 \%)^{15)}, 35$ 例中なし ${ }^{16)}, 32$ 例中 3 例 (9 \%) ${ }^{17)}$ と頻度の低い転移形式である。

本症例は左大腿への骨格筋転移による症状で受 診したが, 肺癌 ${ }^{18)}$, 胃癌 ${ }^{199}$ ともに骨格筋への転移は まれと報告されている。

本症例は胃病変が粘膜下腫瘍様の形態でbull's eye signを呈しており，肺癌胃転移と診断するこ とがより適切であると考えた。しかし，本症例で は胃が原発である可能性を否定することは困難で あると思われた。

\section{結語}

肺と胃に病変を有し，胃病変の粘膜下腫瘍様の 
形態から肺癌胃転移と考えられる 1 例を報告し た。肺癌胃転移, 粘膜下腫瘍様原発性胃癌につい て若干の文献的考察を加えた。

\section{参考文献}

1) Pomerantz $\mathrm{H}$, Margolin $\mathrm{H}$ : Metastases to the gastrointestinal tract from malignant melanoma. Am J Roentgenol 88 : 712-717, 1962

2) Rubin SA, Davis M : "Bull's eye" or "Target" lesions of the stomach secondary to carcinoma of the lung. Am J Gastroenterol 80 : 67-69, 1985

3）佐野量造：胃疾患の臨床病理. 医学書院, 東京, 1974, p91-92

4) Davis JH, Zollinger RW : Metastatic melanoma of the stomach. Am J Surg 99 : 94-96, 1960

5) Scobie BA:Malignant gastric ulcer due to metastasis. Aust Radiol $10: 119-123,1960$

6) Menuck LS, Amberg JR: Metastatic disease involving stomach. Dig Dis 20 : 903-913, 1975

7）上原克昌, 飯島耕作, 長谷川紳治他：肺癌の消化 管転移一肺癌剖検例1775例の検討一。外科41： 1364-1367, 1979

8) Sendo $T$ : Metastasis of 400 necropsy cases of bronchogenic carcinoma: statistical and morphological studies. Med J Osaka Univ 7 :515550, 1956

9）熊谷謙二, 内海邦輔，佐藤 武：昭和 26 年以降本 院において剖検した原発性肺癌についての臨床 病理学的検討. 医療 $19: 49-52,1965$
10）森田豊彦：教室における最近 17.5 年間の肺癌剖 検例一肺癌399例の臨床病理学的解析一。癌の臨 $22: 1323-1337,1976$

11）福山隆之, 平岡哲朗, 蜂谷 勉他：粘膜下腫瘍様 形態を示した胃癌一内視鏡的検討を中心に一，消 化器科 $8: 158-170,1988$

12）武本憲重，馬場保昌，加来幸生他：粘膜下腫瘍の 形態を示した胃癌のX線診断。胃と腸 $30 ： 759$ 768, 1995

13）河田佳代子, 石黒信吾, 辻 直子他：粘膜下腫瘍 様形態を示す胃癌の臨床病理学的特徵. 胃と腸 $30: 739-746,1995$

14）小土井淳則，田中信治，島本丈裕他：粘膜下腫瘍 様形態を呈した胃癌の 1 胃. Gastroenterol Endosc36 : 343-350, 1994

15）金上晴夫, 桂 敏樹, 仁井谷久他：胃癌の肺転移. 日胸臨 $25 ： 485-491 ， 1966$

16）山内晶司, 山田栄吉, 宮石成一他：胃癌の肺転移. 癌の臨28：1243-1248, 1982

17）梅原靖彦, 宮原 透, 吉田雅行他：胃癌肺転移症 例の臨床病理学的検討。日消外会誌 $22 ： 2772-$ 2777,1989

18）森木康之, 浜田史洋, 西山 宜他：大腿内側広筋 内に孤立性転移をきたした肺腺癌の 1 例. 日臨外 会誌60：1809-1815，1999

19）湯橋崇幸，吉井修二，湯橋十善他：骨格筋転移を 来した胃癌の 1 例。日臨外会誌 $60 ： 3167-3171$, 1999 